\title{
ANALISIS DAN PERANCANGAN SISTEM RESERVASI PAKET WISATA UNTUK INTERNAL KARYAWAN PT. GARUDA MAINTENANCE FACILITY (GMF) TBK
}

\author{
Angelina Ervina Jeanette Egeten ${ }^{1}$, Lya Santi Rahayu ${ }^{2}$, Riansyah Rafsanjani ${ }^{3}$ \\ ${ }^{1,2,3}$ Universitas Bina Nusantara \\ Email : ${ }^{1}$ angelina.egeten@binus.ac.id, ${ }^{2}$ lya.santy@gmail.com, \\ ${ }^{3}$ riansyahrafsanjani.jtk11@gmail.com
}

\begin{abstract}
ABSTRAK
PT. Garuda Maintenance Facility (GMF) merupakan anak perusahaan Garuda Indonesia yang setiap tahunnya telah memberikan fasilitas tiket gratis setiap tahun kepada seluruh karyawan tetapnya, namun sebagian besar kayawannya memiliki kendala dalam melakukan reservasi paket wisata karena kurangnya pengetahuan tentang tempat wisata. Tujuan dari penelitian ini adalah untuk memberikan solusi kepada karyawan PT. GMF dalam melakukan reservasi paket wisata, dan sekaligus dapat menjadi solusi berupa peluang bisnis Koperasi Karyawan Garuda Maintenance Facility AeroAsia Sejahtera (KopKar GMF AAS) disektor baru yaitu pariwisata. Penelitian ini menggunakan metode wawancara, observasi dan studi pustaka untuk mengumpulkan data pendukung penelitian, sedangkan metode analisis dan perancangannya menggunakan object oriented analysis and design (OOAD). Hasil penelitian adalah berupa rancangan sistem yang nantinya dapat memberikan kemudahan bagi karyawan yang akan melakukan reservasi paket wisata, serta solusi bisnis bagi KopKar GMF AAS. Karyawan PT. GMF sebagai user dari sistem reservasi paket wisata, dan KopKar GMF AAS sebagai admin (pengelola) sistemnya. Analisis dan perancangan sistem reservasi paket wisata ini meliputi 4 proses utama, yaitu create travel plan, booking paket travel, payment confirmation dan manage transaction.
\end{abstract}

Kata kunci : Sistem Informasi, Perancangan sistem reservasi paket wisata, OOAD, sistem internal karyawan

\section{ABSTRACT}

PT. Garuda Maintenance Facility (GMF) is a member of Garuda Indonesia, which provides free ticket facilities every year for its permanent employees. However, most of its employees have problems in making tour package reservations due to the lack of knowledge of tourist attractions. The purpose of this research is to provide solutions for PT. GMF employees in making tour package reservations, and it can be the solution for Koperasi Karyawan Garuda Maintenance Facility AeroAsia Sejahtera (KopKar GMF AAS) business opportunities in tourism sector. This research is using the interview method, observation, and literature review to compile the research supporting data, whereas the analysis method and design is using object-oriented analysis and design (OOAD). The result of this research is a form of system design which provides convenience for the employees who are making tour package reservations, as well as a business solution for KopKar GMF AAS. PT. GMF employees as the user of the tour package reservations user, and KopKar GMF AAS as the admin (administrator) of the system. The analysis and the development of this tour package reservations system include four main processes, which are creating travel plan, booking the travel package, payment confirmation, and managing transactions.

\section{Keyword : Information System, Designing Travel Package Reservation System, OOAD, Internal System}

Author Korespondensi (Angelina Ervina Jeanette Egeten)

Email : angelina.egeten@binus.ac.id

\section{PENDAHULUAN}

Koperasi adalah usaha yang didirikan oleh orangorang atau badan hukum koperasi yang memiliki masalah ekonomi, yang bertujuan untuk meningkatkan kesejahteraan anggotanya [10]. Koperasi Karyawan Garuda Maintenance Facility AeroAsia Sejahtera (KopKar GMF AAS) adalah koperasi yang beranggotakan seluruh karyawan tetap PT. Garuda Maintenance Facility (GMF) dengan jumlah 4131 [12], yang bergerak dibidang saving and loan, retail and service, procurement, food and beverage, technical service, property project, transportation and logistics. Berdirinya KopKar GMF AAS 
bertujuan untuk mengembangkan potensi ekonomi dan kreatifitas anggotanya yang berujung pada peningkatan kualitas kehidupan anggota dengan cata membangun usaha bersama dalam wadah organisasi. Seiring perkembangan, KopKar GMF AAS bermaksud mengembangkan usahanya dengan membuka jasa penjualan paket wisata kepada anggotanya yang setiap tahunnya telah memiliki tiket gratis dari PT. GMF. KopKar GMF AAS bermaksud sekaligus memberikan solusi atas masalah yang dihadapi anggotanya yang merupakan karyawan PT. GMF yang memiliki kendala melakukan reservasi paket wisata karena kurangnya pengetahuan tentang pariwisata, sehingga karyawan PT. GMF tidak dapat mengoptimalkan fasilitas yang telah diberikan perusahaan.

Tujuan dari penelitian ini adalah merancang sistem reservasi paket wisata KopKar GMF AAS dan memberikan solusi bisnis pada KopKar GMF AAS untuk mengembangkan usahanya. Adapun manfaat yang diperoleh dari implementasi perancangan sistem reservasi ini adalah memudahkan karyawan untuk melakukan reservasi paket wisata dan menambah peluang bisnis bagi KopKar GMF AAS. Penelitian sejenis juga terdapat dalam jurnal internasional yang diterbitkan oleh International Journal of Computer Trends and Technology (IJCTT) volume 22 Number 1-April 2015, dengan judul "Online Holiday Planning and Booking System with Mobile Compatibility" [3], yang membahas tentang perencanaan dan reservasi paket wisata dengan harga ekonomis yang memudahkan member aplikasinya untuk reservasi secara online, yang membedakan penelitian tersebut dengan penelitian ini adalah pada sisi customernya. Penelitian sejenis juga terdapat pada junal internasional IEEE 2017 " Customizing Travel Packages with Interactive Composite Items" [9], yang membahas tentang perancangan aplikasi reservasi paket wisata secara online yang memungkinkan customer melakukan customizing detail paket wisatanya agar lebih nyaman bagi customer.

\subsection{Koperasi}

Koperasi berasal dari bahasa latin "coopere" yang dalam bahasa inggris "cooperation", co berarti besama dan operation berarti bekerja, sehingga cooperation berarti bekerja bersamasama. Jadi koperasi adalah suatu organisasi yang beranggotakan beberapa orang yang berbadan hukum dan bekerjasama secara kekeluargaan untuk menjalankan usaha yang bertujuan untuk menyejahterakan anggotanya [6]. Salah satu peran dan fungsi koperasi adalah memberikan manfaat dan kemudahan bagi anggotanya serta membangun dan mengembangkan potensi dan kemampuan ekonomi anggota untuk meningkatkan kesejahteraan ekonomi dan social [6]. Terdapat tiga jenis koperasi menurut kegiatan usahanya [6]:

a) Koperasi konsumen, yaitu koperasi yang usahanya memenuhi kebutuhan seharihari anggotanya.

b) Koperasi produsen, yaitu koperasi yang usahanya dari proses menghasilkan produk yang kemudian dipasarkan melalui koperasi.

c) Koperasi simpan pinjam, yaitu koperasi yang bergerak udah simpan pinjam kepada anggotanya.

Badan usaha koperasi dimiliki oleh anggota, yang merupakan pemakai jasa atau user, hal yang ini membedakan koperasi dengan badan usaha bentuk lainnya yang didasarkan pada investornya [10]. Koperasi adalah suatu perkumpulan yang didirikan oleh orang-orang atau badan hukum koperasi yang dilatarbelakangi oleh keterbatasan kemampuan ekonomi, dengan tujuan untuk memperjuangkan peningkatan kesejahteraan anggotanya [4].

\subsection{Pariwisata}

Pariwisata berarti kegiatan perjalan yang dilakukan secara sukarela yang bersifat sementara dengan tujuan menikmati objek wisata untuk mencari kenikmatan dan pemenuhan rasa ingin tahu tentang suatu tempat baru [13]. Menurut UU no. 10 tahun 2009 tentang kepariwisataan, yang dimaksud pariwisata adalah :

a) Wisata adalah kegiatan yang dilakukan seseorang untuk mengunjungi tempat tertentu dengan tujuan rekreasi, pengembangan pribadi yang dilakukan dalam jangka waktu sementara.

b) Wisatawan adalah orang yang melakukan wisata.

c) Kepariwisataan adalah semua aktifitas yang terkait dengan pariwisata, termasuk kebutuhan setiap orang untuk berinteraksi dengan sesama wisatawan, masyarakat setempat, pemerintah dan pengusaha.

d) Daya Tarik wisata adalah segala keunikan, keindahan, dan nilai keragaman kekayaan 
alam, budaya dan hasil buaran manusia yang menjadi tujuan kunjungan wisatawan.

e) Destinasi pariwisata adalah daerah tujuan pariwisata.

f) Usaha pariwisata adalah semua usaha yang menyediakan barang / jasa pemenuhan segala kebutuhan wisatawan.

g) Pengusaha pariwisata adalah orang atau organisasi yang membuka peluang usaha pariwisata.

h) Industri pariwisata adalah kumpulan usaha pariwisata yang salah terkait yang kesemuanya menghasilkan barang / jasa bagi pemenuhan kebutuhan wisatawan dalam penyelenggaraan pariwisata.

i) Kawasan strategis pariwisata adalah kawasan yang memilki potensi untuk dikembangkan sebagai lokasi pariwisata.

j) Kompetensi adalah seperangkat pengetahuan, ketrampilan, dan perilaku yang harus dimiliki oleh pekerja pariwisata.

k) Sertifikasi adalah proses pemberian sertifikar dari lembaga tertentu untuk meningkatkan mutu produk pariwisata, pelayanan dan pengelolaan kepariwisataan.

1) Pemerintah pusat adalah pemerintah adalah presiden Republik Indonesia.

m) Pemerintah daerah adalah gubernur, bupati, walikota dan perangkat daerah sebagai unsur penyelenggara pemerintah daerah.

n) Menteri adalah menteri yang memiliki tugas dan tanggung jawab dibidang kepariwisataan.

Pariwisata berkembang karena adanya gerakan manusia dalam mencari sesuatu yang belum diketahuinya, menjelajahi wilayah baru, mencari perubahan suasana, atau untuk mendapatkan kesenangan dari perjalanan baru [7]. Tujuan seseorang melakukan perjalanan adalah untuk memperoleh berbagai tujuan dan memuaskan bermacam keinginan [5].

Konsep perjalanan wisata adalah perencanaan perjalanan wisata yang dilakukan seseorang atau kelompok ke tempat atau obyek wisata dengan memperhatikan potensi dan kemampuan obyek wisata. Semakin besarnya minat orang melakukan perjalanan wisata, maka akan menuntut peningkatan pusat pelayanan penyedia jasa wisata, seperti jasa biro perjalanan wisata yang dapat menyediakan alternatif transportasi, penginapan, tour guide, rekomendasi landmark daerah tujuan wisata, dan lainnya, yang bertujuan untuk memudahkan orang dalam berwisata [1]. Jadi kegiatan wisata merupakan kebutuhan orang untuk memuaskan diri biasanya dengan tujuan refreshing, dan dalam membuat planning wisata dan biasanya menggunakan bantuan biro perjalanan wisata.

\subsection{E-commerce}

E-commerce merupakan proses pembelian, penjualan, pertukaran barang / jasa dan informasi yang dilakukan secara elektronik menggunakan media internet [2]. Berdasarkan sifat transaksinya, e-commerce dibagi menjadi 11 kategori, yaitu sebagai berikut :

a) Business-to-Business (B2B) adalah transaksi yang penjual dan pembelinya adalah perusahaan atau organisasi.

b) Business-to-Cunsumer (B2C) adalah transaksi dalam skala kecil yang melibatkan organisasi sebagai penjual dan individu sebagai pembelinya.

c) Business-to-Business-to-Consumer (B2B2C) adalah kondisi jual beli dimana perusahaan menyediakan produk ke perusahaan lain, yang kemudian dijual ke individu yang bertindak sebagai konsumen.

d) Consumer-to-Business (C2B) adalah individu menjual produk menggunakan media internet kepada perushaan yang berperan sebagai konsumen.

e) Mobile Commerce (M-Commerce) merupakan tipe e-commerce yang melakukan transaksi jual beli menggunakan media jaringan tanpa kabel.

f) Intrabusiness E-commerce adalah segala aktifitas bisnis termasuk proses pertukaran produk dan informasi antar unit dan individu yang terdapat pada suatu perusahaan.

g) Business-to-Employee (B2E) adalah perusahaan menyediakan pelayanan, informasi dan produk pada individu pegawainya.

h) Collaborative Commerce yaitu kolaborasi secara online pada individu atau group dalam proses jual beli.

i) Non-Business E-Commerce merupakan e-commerce yang dilakukan organisasi yang tidak berorientasi untuk mendapatkan keuntungan, misalnya intitusi akademis, organisasi sosial dan lainnya.

j) E-government adalah e-commerce yang digunakan oleh pemerintah. 
Business to Employee (B2E) merupakan salah satu jenis e-business dimana perusahaan memberikan dan menyediakan produk kepada internal karyawannya. B2E menggunakan jaringan bisnis intrabusiness yang memungkinkan perusahaan menyediakan produk dan jasa kepada karyawan [8].

\section{METODOLOGI}

Metodologi yang digunakan dalam penelitian ini dibagi menjadi dua, yaitu Metode Pengumpulan Data dan Metode Analisis dan Perancangan Sistem.

Metode Pengumpulan Data pada penelitian ini terdiri dari wawancara, observasi dan studi pustaka. Wawancara yaitu cara pengumpulan data dan informasi terkait masalah yang dihadapi dan kebutuhan sistem oleh pihak Koperasi Karyawan Garuda Maintenance Facility AeroAsia Sejahtera (KopKar GMF AAS) selaku admin aplikasi dan perwakilan PT. Garuda Maintenance Facility (GMF) selaku obyek penelitian ini. Yang kedua adalah observasi, yaitu mengamati kebutuhan karyawan PT. GMF selaku anggota KopKar GMF AAS yang telah memiliki tiket pesawat tetapi memiliki kesulitan berwisata. Yang ketiga adalah studi pustaka yaitu mempelajari semua teori-teori yang berkaitan dengan analisa dan perancangan sistem berupa buku dan jurnal sebelumnya.

Metode Analisa dan Perancangan menggunakan object oriented analysis and design (OOAD) dalam melakukan perancangan sistem reservasi paket wisata, dengan menggunakan Unified Modelling Language (UML) yang terdiri dari Activity Diagram, Use Case Diagram, Use Case Description, Domain Model Class Diagram, Sequence Diagram, dan Design User Interface versi Satzinger.

\section{HASIL DAN PEMBAHASAN}

\section{a. Proses Bisnis yang Berjalan}

Semua karyawan PT Garuda Maintenace Facility (GMF) yang telah berstatus pegawai tetap akan mendapatkan fasilitas tiket free dengan pilihan destinasi semua rute Garuda Indonesia. Proses penukaran karyawan PT. GMF dapat mengisi form pengajuan tiket yang telah disediakan oleh unit Human Capital Management, yang selanjutnya akan divalidasi oleh staff bagian Travel Mangement, apabila semua persyaratan sesuai, maka bagian Travel Mangement akan issued tiket perjalanan, dan tiket yang telah diissued masih dapat dilakukan reschedule atau reroute dengan batas waktu $\mathrm{H}$ 7. Selain mengisikan form pencairan tiket, karyawan pelu menyertakan photocopy ID card ke Bagian Travel Mangement.

\section{b. Analisis Masalah Perusahaan}

Dalam penelitian ini terdapat dua masalah utama yaitu masalah yang dihadapi karyawan PT. GMF dan masalah yang dihadapi KopKar GMF AAS. Adapun masalah yang dihadapi karyawan PT. GMF adalah kendala dalam berwisata karena tidak memiliki gambaran biaya dan lama wisata pada lokasi tujuan wisata, sehingga KopKar GMF AAS bermaksud memberikan solusi kepada karyawan untuk memberikan layanan reservasi paket wisata exclude tiket. Masalah yang kedua adalah KopKar GMF AAS bermaksud mengembangkan usahanya dengan membuka jasa penjualan paket wisata ke anggotanya yang merupakan karyawan PT. GMF AA. Paket wisata yang dijual meliputi paket wisata tour di lokasi tujuan wisata.

\section{c. Usulan Pemecahan Masalah}

Berdasarkan masalah yang dihadapi karyawan PT. GMF dan KopKar GMF AAS, maka dapat diberikan usulan dengan membangun perancangan sistem reservasi paket wisata khusus untuk internal karyawan PT. GMF yang akan dikelola oleh KopKar GMF AAS. KopKar GMF AAS sebagai adminnya dan karyawan PT. GMF sebagai customernya. Solusi hanya sampai pada analisa dan perancangan sistem, dan tidak membahas implementasi sistem dan uji coba sistem.

\section{d. Perancangan Sistem Informasi}

1) Prosedur Proses Create Travel Plan

Create Travel Plan adalah aktifitas yang dilakukan oleh user (karyawan PT. GMF) untuk membuat rencana wisata dengan memilih tanggal perjalanan, pemilihan lokasi wisata yang tidak memerlukan login, sistem akan menampilkan jumlah nominal yang dibutuhkan untuk wisata.

2) Prosedur Proses Booking Paket Travel Create booking dilakukan oleh user (karyawan PT. GMF) setelah melakukan create travel plan dan telah menyetujui detail harga yang ditampilkan sistem, yang selanjutnya user diharuskan melengkapi form pemesanan dan data pemesanan selanjutnya disimpan oleh sistem dan ditampilkan pada layar pemesanan.

3) Prosedur Payment Confirmation 
Check payment detail adalah aktifitas lanjutan setelah user (kayawan PT. GMF) melakukan pemesanan, yang selanjutnya akan menampilkan tatacara pembayaran selanjutnya user memilih cara pembayaran dan memilih konfirmasi pembayaran, sistem akan menyimpan data konfirmasi pembayaran.

4) Admin Manage Transaction

Admin (KopKar GMF AAS) dapat melakukan pengecekan status pembayaran dan selanjutnya akan mengubah status pembayaran menjadi paid. Untuk pelaporan sistem dapat mengeluarkan report transaksi yang hanya dapat diakses oleh admin. Dalam kondisi tertentu admin dapat mengirimkan notifikasi berupa email ke semua customer pemberitahuan penggantian rute wisata yang dikarenakan keadaan urgent, misalnya bencana alam dan lainnya.

\section{Activity Diagram}

Perancangan sistem yang diusulkan dapat dibagi menjadi empat aktifitas utama, yaitu aktifitas create travel plan, aktifitas create booking, aktifitas payment confirmation dan aktifitas manage transaction oleh user admin.

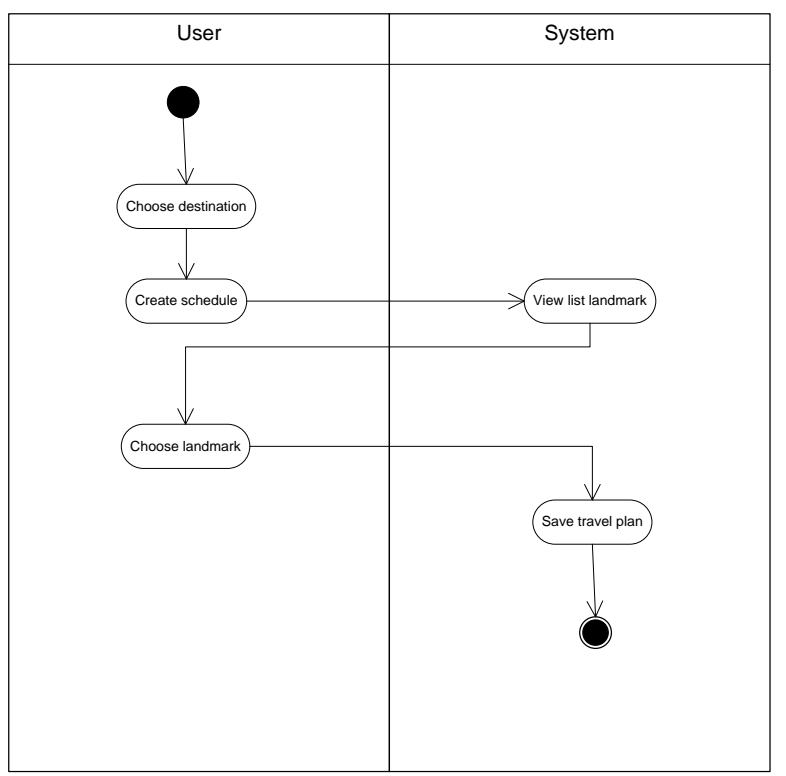

Gambar 1.1 Activity Diagram Create Travel Plan

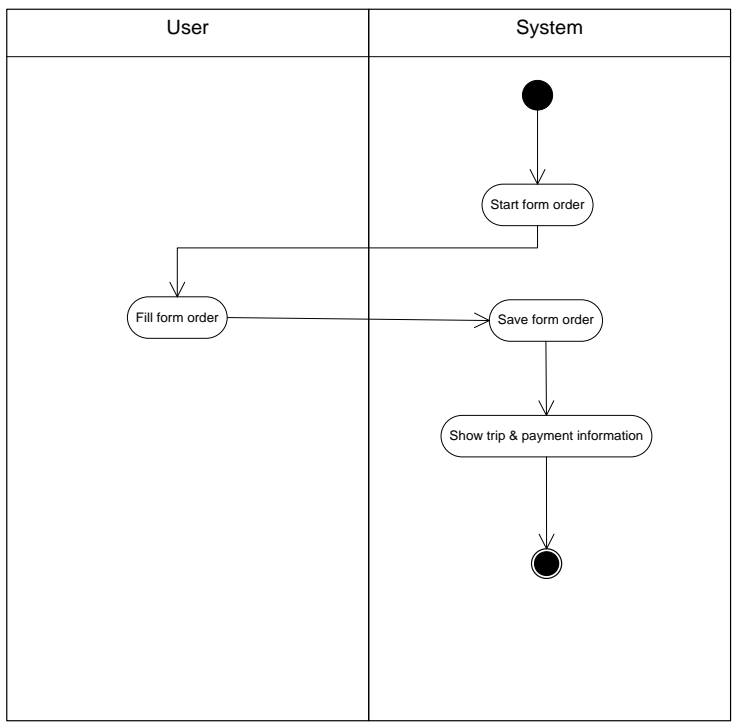

Gambar 1.2 Activity Diagram Create Booking

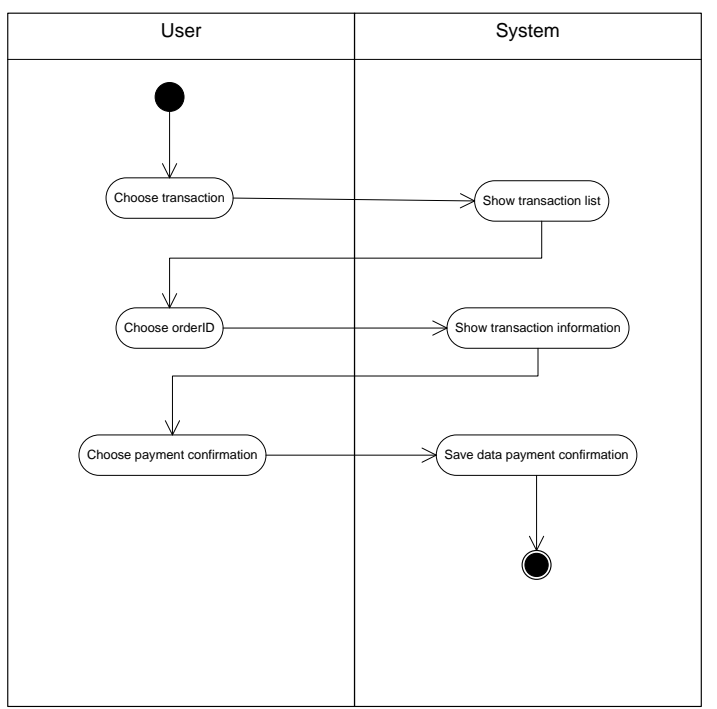

Gambar 1.3 Activity Diagram Payment Confirmation

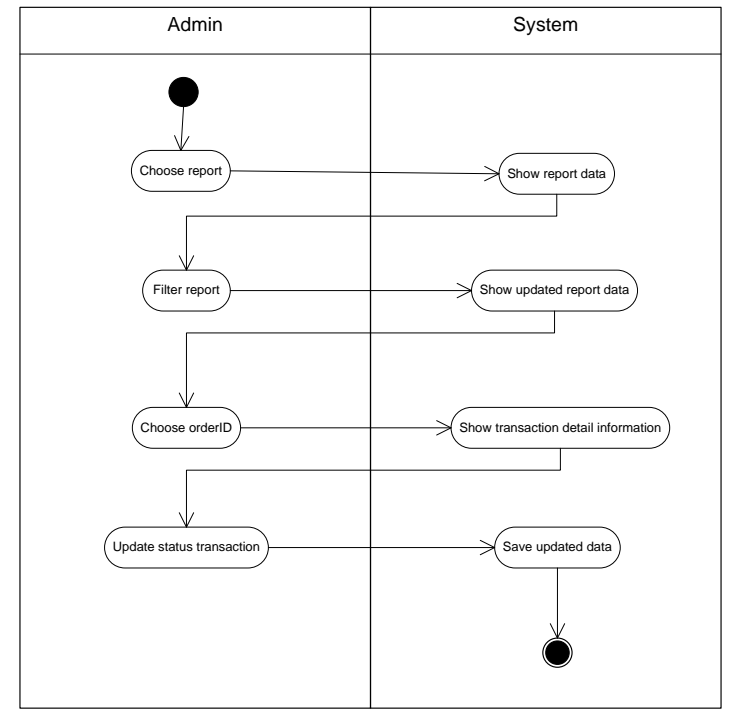

Gambar 1.4 Activity Diagram Manage Transaction 


\section{Use Case Diagram}

Perancangan sistem yang diusulkan dapat digambarkan dengan user case berikut :

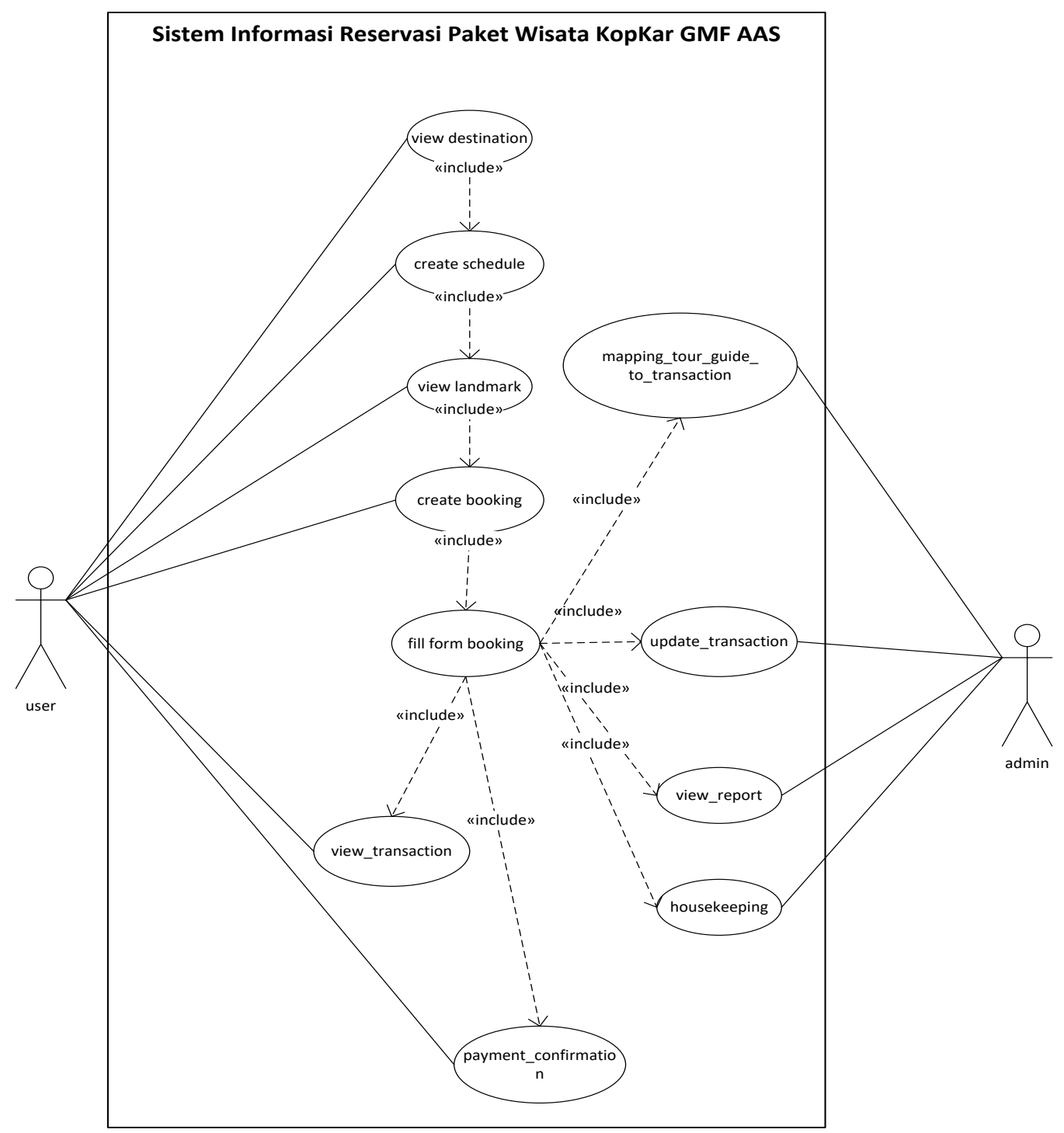

Gambar 1.5 Use Case Sistem Informasi Reservasi Paket Wisata KopKar GMF AAS

\section{Brief Use Case Description}

Tabel 1.1 Use Case Brief Description

\begin{tabular}{|l|l|l|}
\hline No & Use Case & Brief Description \\
\hline 1 & View destination & Pemilihan destinasi wisata oleh user. \\
\hline 2 & Create schedule & $\begin{array}{l}\text { User setelah memilih destinasi, maka dapat dilanjutkan dengan } \\
\text { membuat jadwal perjalanan wisata. }\end{array}$ \\
\hline 3 & View landmark & $\begin{array}{l}\text { User dapat memilih landmark yang tersedia berdasarkan } \\
\text { destinasi yang dipilih. }\end{array}$ \\
\hline 4 & Create Booking & User memilih Menu Booking. \\
\hline 5 & Fill form booking & User melengkapi isian detail data yang muncul di layar. \\
\hline 6 & $\begin{array}{l}\text { Payment } \\
\text { confirmation }\end{array}$ & $\begin{array}{l}\text { User melakukan konfirmasi pembayaran dari transaksi yang } \\
\text { telah dilakukan. }\end{array}$ \\
\hline 7 & View transaction & User dapat melihat rincian transaksi berdasarkan order \\
\hline
\end{tabular}




\begin{tabular}{|l|l|l|}
\hline No & Use Case & Brief Description \\
\hline 8 & $\begin{array}{l}\text { Mapping tour } \\
\text { guide } \\
\text { transaction }\end{array}$ & $\begin{array}{l}\text { User akan memilih tour guide dari tampilan opsi yang ada, } \\
\text { pemilihan ini dapat dilakukan setelah transaksi berhasil. }\end{array}$ \\
\hline 9 & View report & $\begin{array}{l}\text { Admin akan dapat melihat dan mengunduh report transaksi } \\
\text { sesuai dengan range tanggal yang telah dipilih. }\end{array}$ \\
\hline 10 & $\begin{array}{l}\text { Update } \\
\text { transaction }\end{array}$ & $\begin{array}{l}\text { Admin dapat melakukan update transaction jika pembayaran } \\
\text { telah sukses, dan admin juga dalam keadaan darurat dapat } \\
\text { mengubah rute perjalanan seluruh user customer yang ada, } \\
\text { misalnya adanya bencana alam di lokasi tujuan wisata. }\end{array}$ \\
\hline 11 & Housekeeping & $\begin{array}{l}\text { Admin dapat melakukan proses download dan delete } \\
\text { transactional data untuk periode tertentu. }\end{array}$ \\
\hline
\end{tabular}

\section{Domain Model Class Diagram}

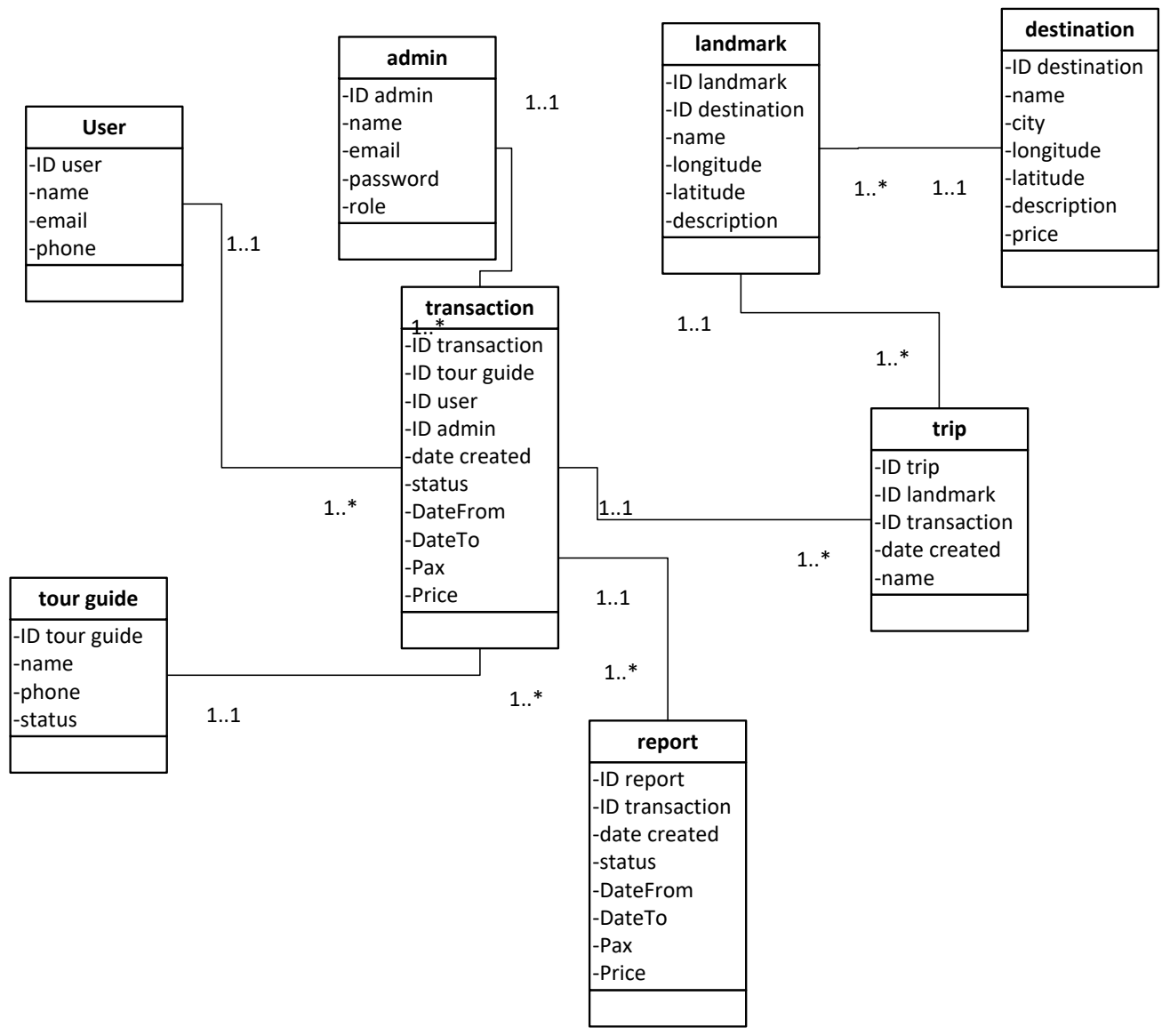

Gambar 1.6 Domain Model Class Diagram

Pada domain model class diagram sistem informasi reservasi paket wisata KopKar GMF AAS terdiri dari 8 class. Class user berassosiasi one to many, karena satu user dapat melakukan transaksi lebih dari satu. Class admin berasosiasi one to many, karena satu admin dapat melakukan update transaksi lebih dari satu. Class tour guide berasosiasi one to many ke transaksi, karena 1 tour guide dapat menghandel lebih dari satu transaksi. Beberapa transaksi dapat dikeluarkan menjadi 1 report yang dapat disort by date atau userid. Satu transaksi dapat memuat beberapa trip. Satu landmark dapat terdiri dari beberapa trip. 


\section{Update Design Class Diagram}

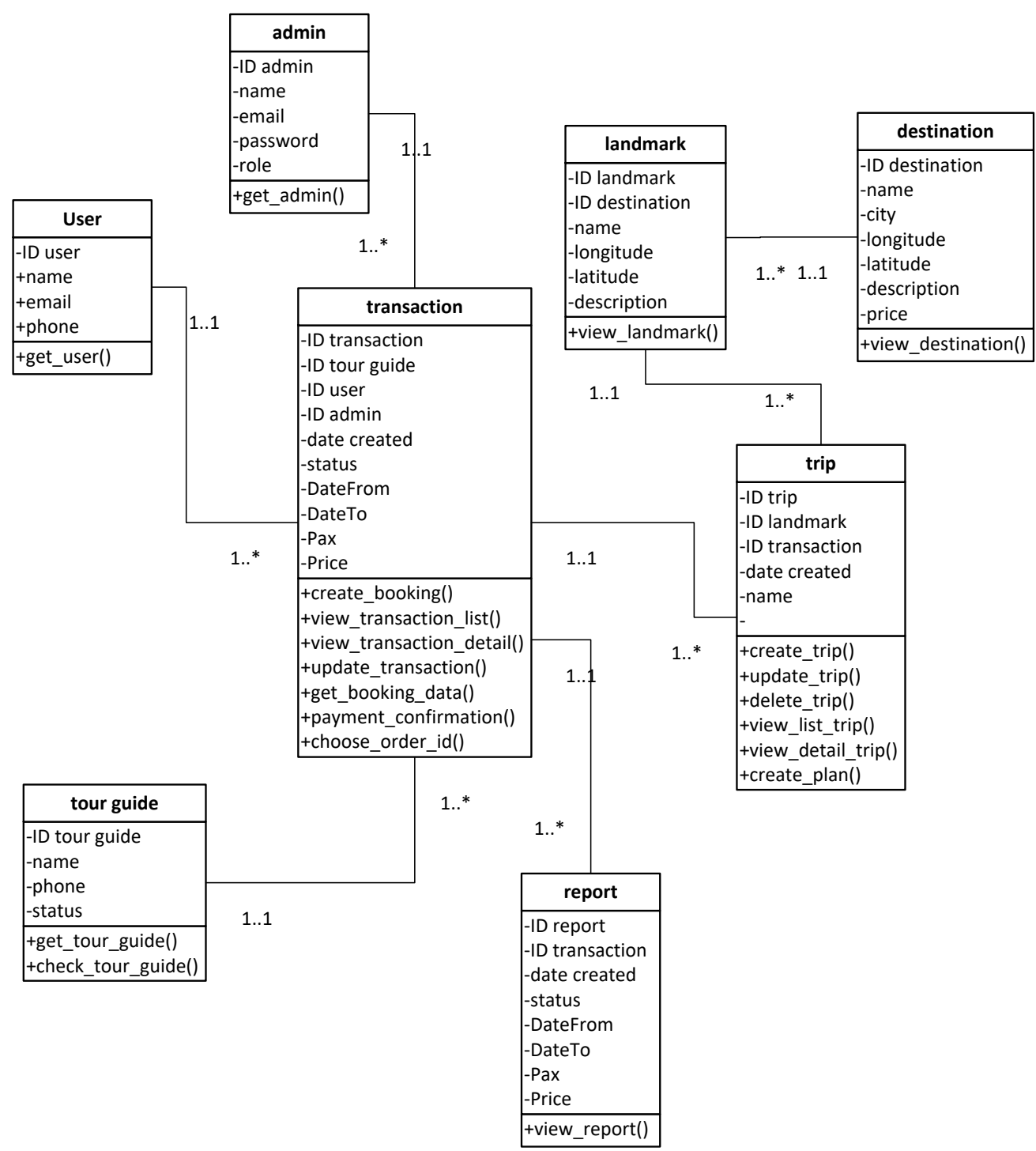

Gambar 1.7 Update Design Class Diagram 


\section{System Sequence Diagram}

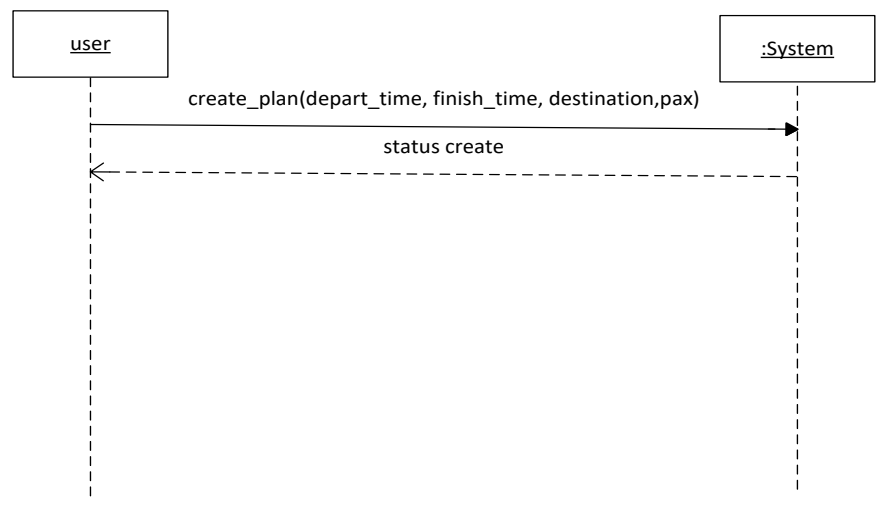

Gambar 1.8 Sequence Diagram Create Schedule

User melakukan aktifitas create_plan (yang memuat informasi depart_time, finish_time, destination, pax), lalu system memberikan balikan ke user berupa status create_plan.

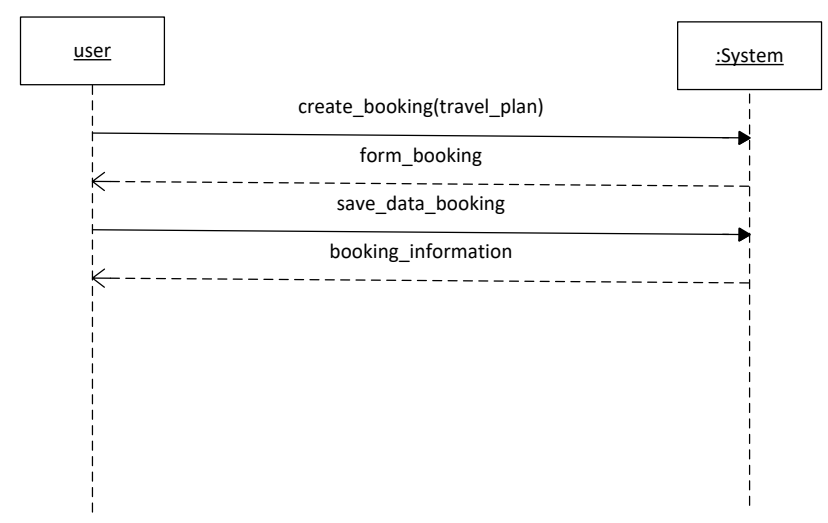

Gambar 1.9 System Sequence Diagram Create Booking

User melakukan create_booking, system memunculkan form_booking, setelah user mengisi form_booking melakukan save data, dan system akan merespon ke user dengan memberikan booking_information. 


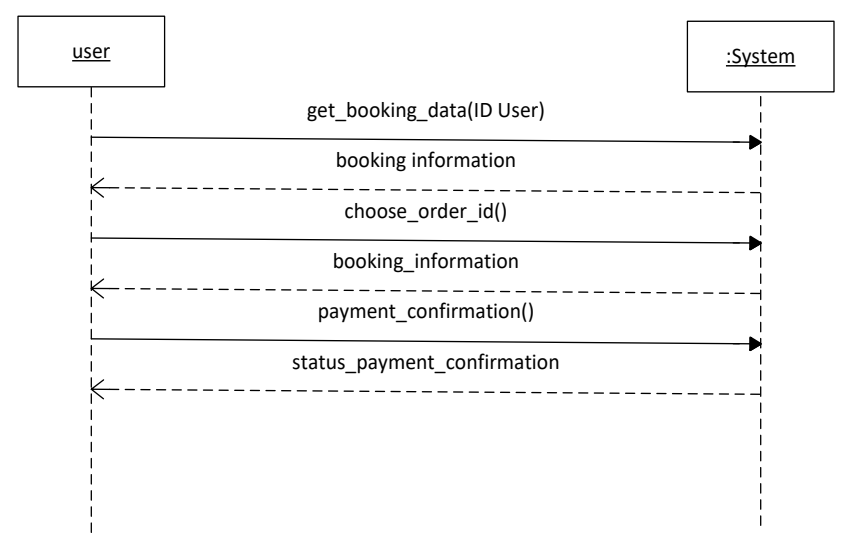

Gambar 1.10 System Sequence Diagram Payment Confirmation

User memilih bookingID, system menampilkan detail data bookingID. Jika bookingID sudah sesuai, maka user melanjutkan ke step payment confirmation, selanjutnya system akan memberikan status payment.

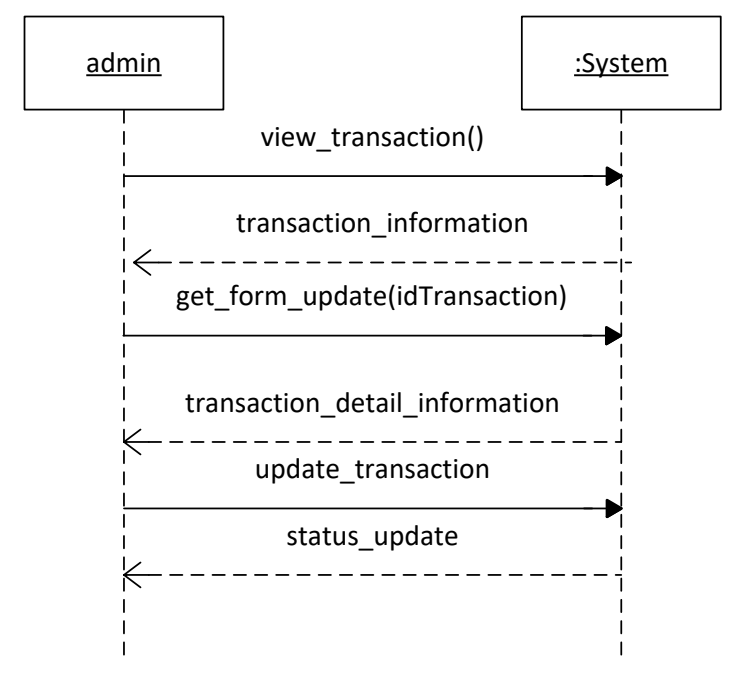

Gambar 1.111 Sequence Diagram Update Transaction

Admin memilih view pada data transaksi, system memberikan detail informasi transaksi, admin dapat mengupdate data transaksi (misalkan mengganti status payment), system memunculkan pop up screen konfirmasi, data transaksi terupdate ke system dan system memberikan notifikasi bahwa data telah berhasil diupdate. 


\section{Design User Interface}

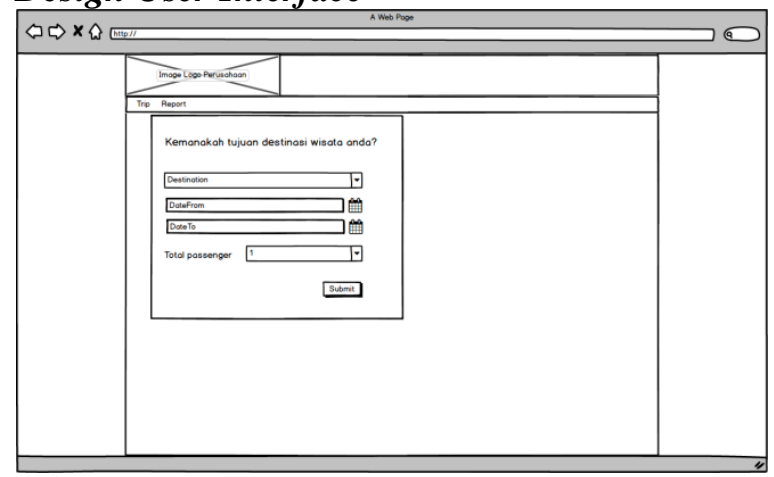

Gambar 1.12 User Interface Create Travel Plan step 1

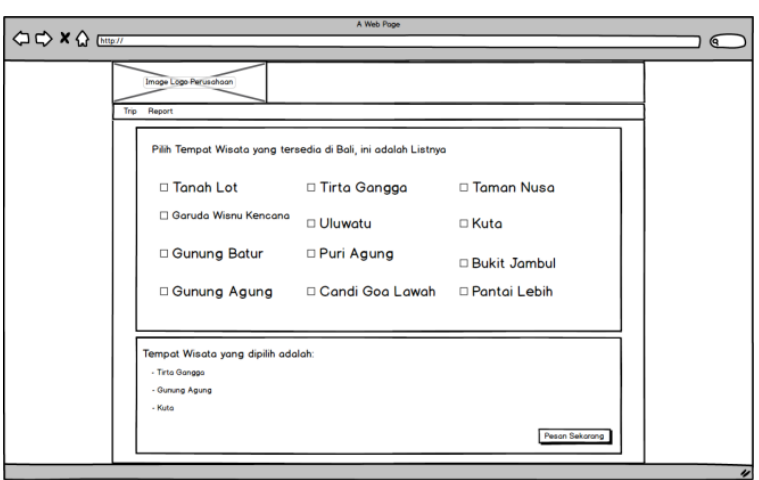

Gambar 1.13 User Interface Create Travel Plan step 2

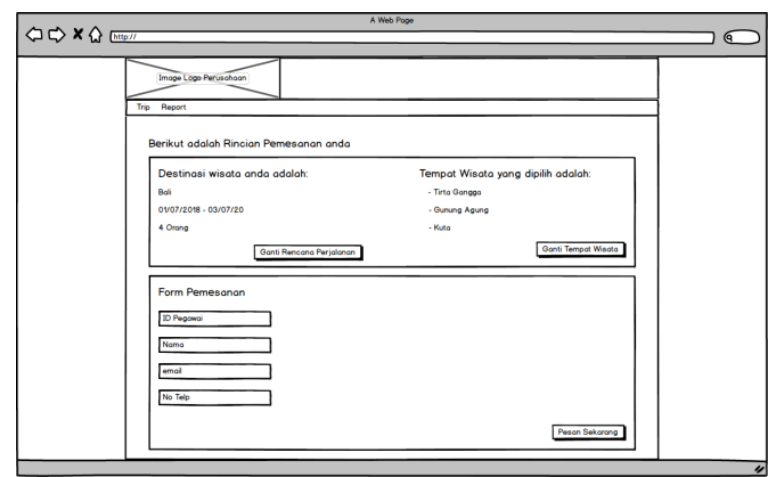

Gambar 1.14 User Interface Fill Booking Form

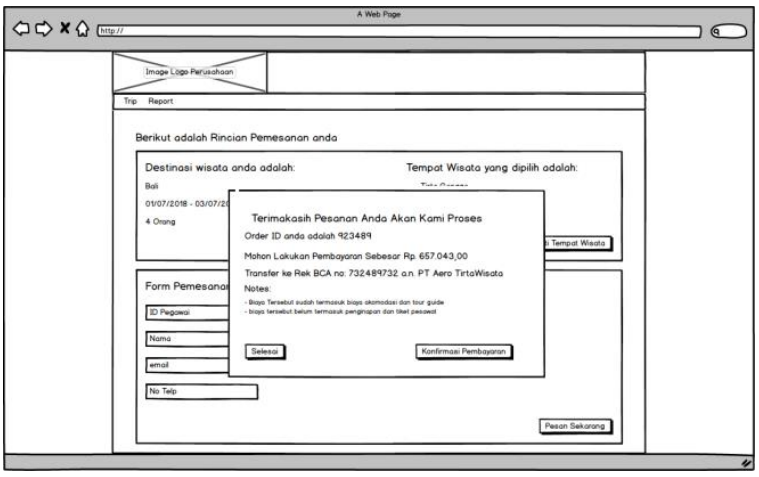

Gambar 1.15 User Interface Payment Confirmation step 1

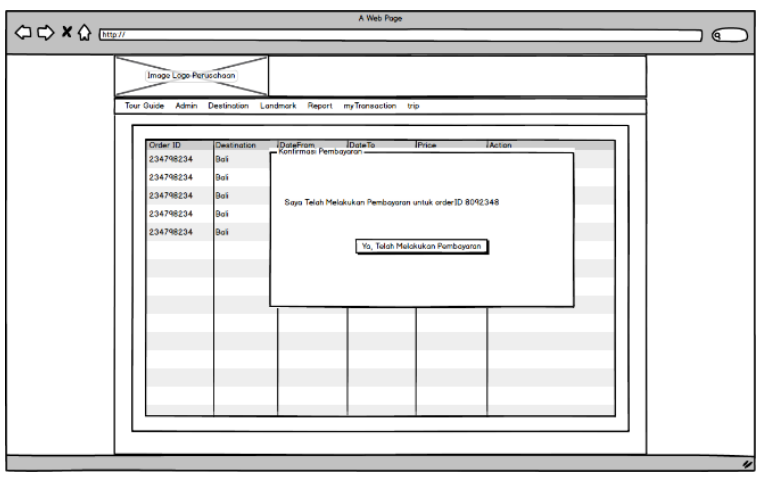

Gambar 1.16 User Interface Payment Confirmation step 2

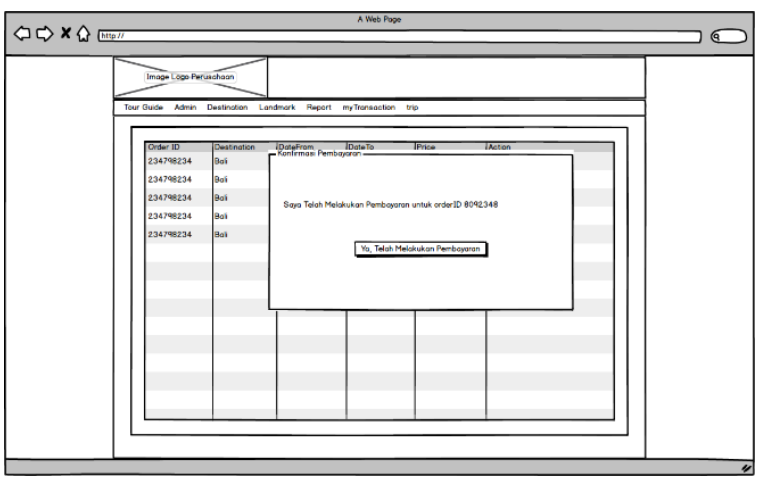

Gambar 1.17 User Interface MyBooking page 1

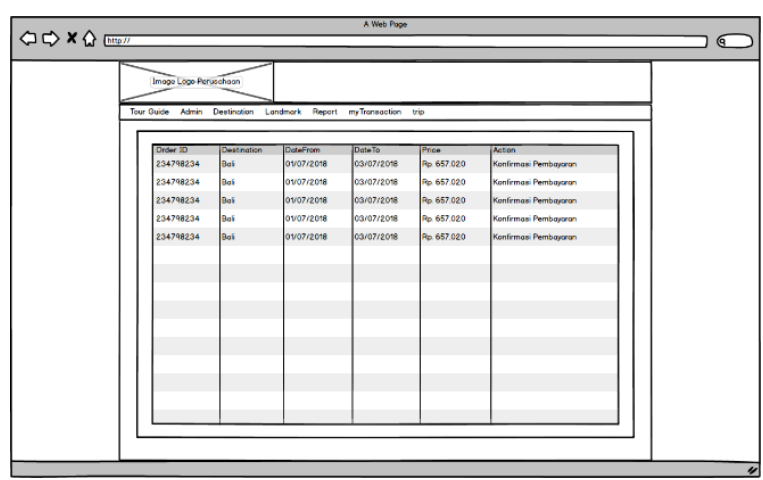

Gambar 1.18 User Interface MyBooking page 2

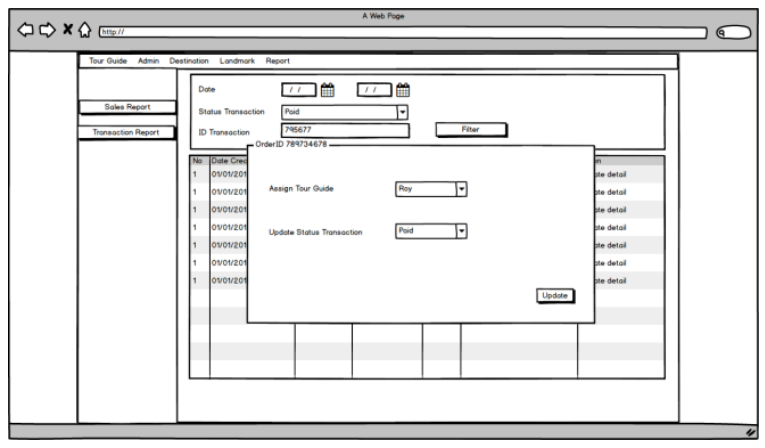

Gambar 1.19 User Interface Admin Update Transaction 


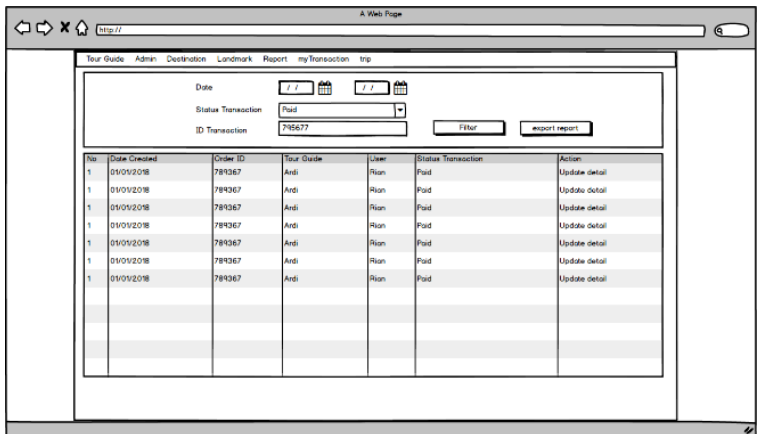

Gambar 1.20 User Interface Admin View Report

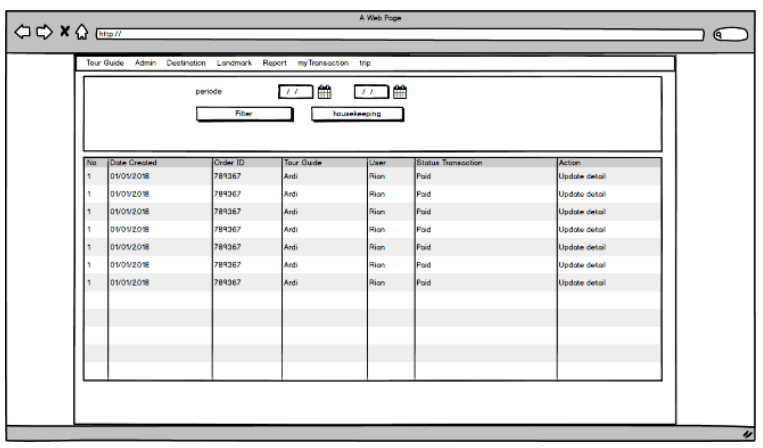

Gambar 1.21 User Interface Housekeeping

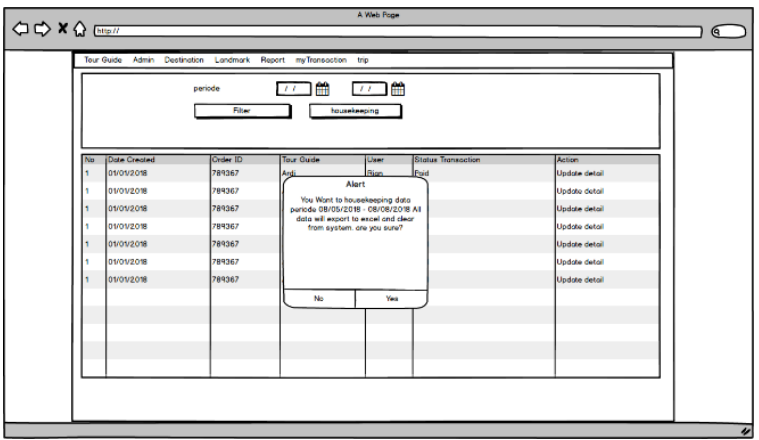

Gambar 1.22 User Interface Housekeeping pop up

\section{SIMPULAN DAN SARAN}

Berdasarkan analisis dan perancangan sistem reservasi paket wisata pada koperasi karyawan PT. Garuda Maintenace Facility (GMF) maka dapat disimpulkan masalah yang ada adalah sebagai berikut :

1. Karyawan PT. GMF memiliki kendala melakukan reservasi paket wisata.

2. KopKar GMF AAS memiliki masalah dalam mengembangkan bisnis dilini lainnya, yang terlihat KopKar GMF AAS berpeluang menjaual paket wisata ke anggotanya yang merupakan karyawan PT. GMF.

Berdasarkan analisis dan perancangan sistem reservasi paket wisata pada koperasi karyawan PT. GMF, maka dapat disimpulkan solusi dari permasalahan yang dihadapai adalah sebagai berikut :

1. Dengan diimplementasikannya sistem reservasi paket wisata yang nantinya akan dikelola oleh KopKar GMF AAS, maka koperasi akan dapat mengembangkan usaha dibidang tour, yang sekaligus menjadi solusi dari masalah yang dihadapi karyawan PT. GMF.

2. Sistem reservasi dirancang untuk internal karyawan PT. GMF yang merupakan anggota KopKar GMF AAS.

3. Perancangan sistem terdiri dari 4 proses utama, yaitu create travel plan, booking paket travel, payment confirmation dan manage transaction.

4. Sistem dapat mengeluarkan report transaksi yang hanya dapat diakses oleh admin yaitu KopKar GMF AAS.

5. Dalam keadaan darurat, admin berhak mengubah rute dengan memberikan notifikasi berupa email ke customer.

6. Semua pegawai tetap PT. GMF otomatis akan dapat mengakses sistem reservasi paket wisata menggunakan nomor pegawai sebagai usernya.

Berikut beberapa saran yang dapat diberikan setelah implementasi rancangan sistem reservasi paket wisata ini :

1. Dapat mengembangkan sistem reservasi paket wisata dengan sistem pencairan tiket yang digunakan oleh bagian HRD, dengan sistem yang terintegrasi, akan semakin memudahkan karyawan karena hanya perlu mengakses web reservasi lalu dilanjutkan step pemilihan paket wisata.

2. PT. GMF dan KopKar GMF AAS dapat bekerjasama untuk mengembangkan sistem pembayaran paket wisata dengan sistem potong gaji dari rekening payroll karyawan setiap tanggal 25.

3. KopKar GMF AAS akan melakukan evaluasi secara periodik untuk memastikan sistem yang diimplementasikan sudah memenuhi kebutuhan karyawan, dan melakukan maintenance sistem secara berkala dan melakukan fixing bugs untuk kestabilan sistem, atau pengembangan penambahan fitur yang disesuaikan dengan kebutuhan internal karyawan. 
4. Analisa dan Perancangan Sistem Reservasi Paket Wisata Untuk Internal Karyawan PT. Garuda Maintenance Facility (GMF) Tbk dapat diimplementasikan dan hingga uji coba sistem.

Kami ucapakan terima kasih kepada Bapak Suhartono selaku narasumber kami pada PT. Garuda Maintenance Facility (GMF) Tbk.

\section{REFERENSI}

[1] Atmaja, E. H. (2014). Manajemen Operasional Paket Wisata City Tour Surakarta di Kirana Tour Yogyakarta. Yogyakarta: Universitas Gadjah Mada.

[2] Chaffey, D. (2011). E-Business and ECommerce Management : Strategy, Implementation, and Practice. Pearson Education.

[3] Husba, Dharani, \& Devi, K. (2015). Online Holiday Planning and Booking System with Mobile Compatibility. International Journal of Computer Trends and Technology (IJCTT), 22.

[4] Kohl, R., \& Abrahamson. (2010). Analisis Kredit Bermasalah. Bandung: Unikom.

[5] Muljadi, A. (2012). Kepariwisataan dan Perjalanan. Jakarta: Raja Grafindo.

[6] Muljono, D. (2012). Buku Pintar Strategi Bisnis Koperasi Simpan Pinjam. Yogyakarta: CV. Andi Offset.

[7] Nieamah, K. F. (2014). Persepsi Wisatawan Mencanegara Terhadap Fasilitas dan Pelayanan Di Candi Prambanan. Jurnal Nasional Pariwisata, ISSN, 1411-9862.

[8] Rainer, \& Cegielski. (2011). Introduction to Information Systems. USA: Wiley.

[9] Singh, M., Borromeo, R., Hosami, A., Yahia, S. A., \& Elbassuoni. (2017). Customizing Travel Packages with Interactive Composite Items. IEEE.

[10] Sudarwanto. (2013). Akuntansi Koperasi. Yogyakarta: Graha Ilmu.

[12] Suhartono. (2018, February 16). Executive Assistant of Director. (L. S. Rahayu, Interviewer)

[13] Suwena, I. K., \& Widyatmaja, I. G. (2010). Pengetahuan Dasar Ilmu Pariwisata. Bali: Udayana University Press. 